\title{
Pacific oyster (Crassostrea gigas) hemocyte are not affected by a mixture of pesticides in short-term in vitro assays
}

\author{
Pierrick Moreau ${ }^{1,{ }^{*}}$, Thierry Burgeot ${ }^{2}$, Tristan Renault $^{1}$
}

\begin{abstract}
${ }^{1}$ Ifremer (Institut Français pour la Recherche et l'Exploitation de la Mer), Unité Santé Génétique et Microbiologie des Mollusques, Laboratoire de Génétique et Pathologie des Mollusques Marins, 17390, La Tremblade, France 2 Ifremer (Institut Français pour la Recherche et l'Exploitation de la Mer), Unité Biogéochemie et Ecotoxicologie, rue de l'lle d'Yeu, 21105, 44311, Nantes, France
\end{abstract}

*: Corresponding author : Pierrick Moreau, pierrick.moreau@ifremer.fr

\begin{abstract}
:
Pesticides are frequently detected in estuaries among the pollutants found in estuarine and coastal areas and may have major ecological consequences. They could endanger organism growth, reproduction, or survival. In the context of high-mortality outbreaks affecting Pacific oysters, Crassostrea gigas, in France since 2008, it appears of importance to determine the putative effects of pesticides on oyster susceptibility to infectious agents. Massive mortality outbreaks reported in this species, mainly in spring and summer, may suggest an important role played by the seasonal use of pesticides and freshwater input in estuarine areas where oyster farms are frequently located. To understand the impact of some pesticides detected in French waters, their effects on Pacific oyster hemocytes were studied through short-term in vitro experiments. Bivalve immunity is mainly supported by hemocytes eliminating pathogens by phagocytosis and producing compounds including lysosomal enzymes and antimicrobial molecules. In this study, oyster hemocytes were incubated with a mixture of 14 pesticides and metaldehyde alone, a molecule used to eliminate land mollusks. Hemocyte parameters including dead/alive cells, nonspecific esterase activities, intracytoplasmic calcium, lysosome number and activity, and phagocytosis were monitored by flow cytometry. No significant effect of pesticides tested at different concentrations was reported on oyster hemocytes maintained in vitro for short-term periods in the present study. It could be assumed that these oyster cells were resistant to pesticide exposure in tested conditions and developing in vivo assays appears as necessary to better understand the effects of pollutants on immune system in mollusks.
\end{abstract}

Keywords: Immunity ; Hemocytes ; Pesticides ; Pacific oyster ; Crassostrea gigas ; Flow cytometry ; Bivalve 


\section{Introduction}

Estuaries are considered among the most productive environments in the world. They serve as nurseries for juveniles of economically important fish and invertebrate larvae, and they also rank among the most contaminated areas. Pesticides have become more frequently detected among the pollutants found in estuarine and coastal areas (Renault, 2011; Masuda et al., 2012; Savage et al., 2012). Pesticides may have major ecological consequences and could endanger organism growth, reproduction or survival (Banerjee et al., 1996). France is one of the first European users of pesticides for agriculture purposes. Given their extensive use and the different pathways of these molecules in watersheds, many pesticides are found in French coastal waters, especially in the different basins of oyster production. The Pacific oyster, Crassostrea gigas, given its phylogenetic position and its economic relevance in aquaculture at a national and international level appears as a model of choice to define the importance of the immune system as a target of pollutants in invertebrates. In the context of high mortality outbreaks affecting Pacific oysters, Crassostrea gigas, in France since 2008, it appears of importance to study the putative effects of pesticides on oyster susceptibility to infectious agents. The effects of environmental contaminants may result from direct toxic actions on tissues or cells or from alterations of the homeostatic mechanisms including the immune system (Coles and Pipe, 1994; Carajaville et al., 1996). Among all physiological processes possibly disturbed by pollutants, the immune system is likely to be particularly sensitive (Baier-Anderson \& Anderson, 2000; Fournier et al., 2000). It has been shown, in vertebrates and invertebrates, that pesticides are capable of diminishing immune defenses and/or of modifying genomes (Vial et al., 1996; Kouassi et al., 2001; Banerjee et al., 1996; Banerjee et al., 2001). It has been also suggested that bivalves may be weakened as a result of the presence of these pollutants, and thus become more vulnerable to infectious diseases (Ross et al., 1996; Gagnaire et al., 2007). 
To understand the impact of pesticides detected in French waters, their effects on Pacific oyster hemocytes were studied through short-term in vitro experiments in the present study. Bivalve immunity is mainly supported by hemocytes that eliminate pathogens by phagocytosis (Cheng, 1981; Feng, 1988) and produce compounds including lysosomal enzymes and antimicrobial molecules which contribute to pathogen destruction (Coles \& Pipe, 1994). Oyster hemocytes were collected in the adductor muscle sinus and incubated either with metaldehyde which is used to kill land mollusks or a mixture of 14 pesticides. In order to reveal potential effects of pesticides, hemocyte parameters including dead/alive cells, non-specific esterase activities, intracytoplasmic calcium, lysosome number and activity and phagocytosis were monitored by flow cytometry. 


\section{Materials and methods}

2.1. $\quad$ Oysters and hemocyte collection

In order to reduce the impact of inter-individual variability on the assessment of hemocyte parameters, Pacific oysters aged less than one year from 3 bi-parental families (Families $n^{\circ} 11, \mathrm{n}^{\circ}$ 29 and $n^{\circ} 32$ ) were used in the present study. They were produced simultaneously and reared under similar conditions at the Ifremer's facilities (LGPMM La Tremblade, France), as part of the European project Bivalife (FP7, 2011-2014, GA n²66157).

Oyster hemolymph was withdrawn from the adductor muscle sinus through a notch ground in the

oyster shell, using a $1 \mathrm{ml}$ syringue equipped with a needle $(0.9$ x $25 \mathrm{~mm})$. Hemolymph samples were filtered on a $60 \mu \mathrm{m}$ mesh to eliminate debris. Hemocytes were counted with a Malassez cell and kept on ice until use to avoid cell aggregation. Pools of cells from 50 oysters were used to provide enough hemocytes to carry out experiments.

\subsection{Pesticides}

Fourteen pesticides were selected based on their detection in the aquatic environment in Brittany and in Charente Maritime and on their immunotoxic potential for invertebrates (Galloway \& Handy, 2003; Tanguy et al., 2005; Gagnaire et al., 2007; Menin et al., 2008; Luna-Acosta et al., 2011). They belong to 4 pesticide groups: herbicides, fongicides, insecticides, and molluscicides. A mixture of 14 pesticides (Table 1) was tested as well as metaldehyde alone. Solvents were used as recommended by manufacturers (Table 1) and final solvent concentration was less than $0.5 \%$ in order to avoid disturbance of hemocyte parameters. All pesticides were purchased from Fluka and Supelco (Sigma-Aldrich).

\subsection{Flow cytometry}


Oyster hemocyte activities were monitored using flow cytometry (EPICS® XL flow cytometer). For each sample, 5000 events were counted using an EPICS XL 4 (Beckman Coulter). Results were depicted as cell cytograms indicating cell size (FSC value) and cell complexity (SSC value) and the fluorescence channel(s) corresponding to the marker used. A gate was defined on the basis of FSC value in order to eliminate cell debris. To measure hemocyte mortality, $200 \mu \mathrm{L}$ of hemolymph were incubated with $10 \mu \mathrm{L}$ of propidium iodide for 30 min on ice in the dark (Gagnaire et al., 2003). Non-specific esterase activities were investigated in $200 \mu \mathrm{L}$ of hemolymph after 30 min incubation in the dark at room temperature with $1 \mu \mathrm{L}$ of FDA (fluorescein diacetate) (Gagnaire et al., 2003). Intracytoplasmic calcium was monitored in $200 \mu \mathrm{L}$ of hemolymph added with $1 \mu \mathrm{l}$ of Fluo-4 AM (Life Technologies: Fluo-4, AM, cell permeant) at $5 \mathrm{mM}$ (1h $30 \mathrm{~min}$ incubation in the dark at room temperature) (Aton et al., 2006). The presence and the number of lysosomes were measured in $200 \mu \mathrm{L}$ of hemolymph supplemented with $1 \mu$ l of Lysotracker ${ }^{\circledR}$ (Invitrogen: Lysotracker ${ }^{\circledR}$ Green DND26) to $1 \mathrm{mM}$ (2h incubation in the dark at room temperature) (Gagnaire et al., 2003). Lastly, the phagocytic activity was followed in $200 \mu \mathrm{L}$ of hemolymph supplemented with $10 \mu \mathrm{L}$ of beads $1 \mu \mathrm{m}$ in diameter (ratio bead / hemocyte: 700/1) with a 2 hour incubation in the dark at room temperature. Cell size and complexity were measured in $200 \mu \mathrm{L}$ of hemolymph incubated for $30 \mathrm{~min}$ in the dark at room temperature without any treatment (Gagnaire et al., 2003).

\subsection{Experimental designs}

\subsubsection{Test of different times of incubation with the pesticides mixture}

Initial assays aimed at evaluating in vitro the effect of a mixture of 14 pesticides on oyster hemocytes (Family $\mathrm{n}^{\circ} 11$ ) after different incubation times. The parametres that were assessed by flow cytometry included: cell size and complexity (data not shown), hemocyte mortality, nonspecific esterases (data not shown), intracytoplasmic calcium, presence and activities of lysosomes and phagocytic activity. The concentration that was tested (1X) corresponded to realistic concentrations reported in the environment (Table 1). 
Oyster hemocytes were incubated with the pesticide mixture during $21 \mathrm{~h}$ and sampled at 3 times: $2 \mathrm{~h}, 4 \mathrm{~h}$ and $21 \mathrm{~h}$. A single pool of filtered hemolymph was prepared from 50 individuals and distributed in tubes including one "control" (the control was not exposed to pesticides, but it corresponds to the same quantity of solvent used for testing the pesticide mixture). After adding the pesticide mixture, tubes were placed at $16^{\circ} \mathrm{C}$ in an incubator in the dark during $21 \mathrm{~h}$. The experiment was repeated three times with 50 oysters for each experiment. Family n 32 was also tested (data not shown).

\subsubsection{Test of different concentrations of the pesticide mixture}

Assays were also carried in order to study the effects of the pesticide mixture at different concentrations. Hemocytes were collected from oysters belonging to Family $\mathrm{n}^{\circ} 29$, and different hemocyte parameters were measured by flow cytometry: cell size and complexity (data not shown), hemocyte mortality, presence of non-specific esterases (data not shown), intracytoplasmic calcium, presence and activities of lysosomes and phagocytic activity.

Concentrations tested (1X : environmentaly relevant concentrations) correspond to realistic concentrations reported in the environment (Table 1) and concentrations 10, 50 and 100 times higher (Table 1). The incubation with the pesticide mixture was $4 \mathrm{~h}$ as hemocyte mortality was reported in controls for longer incubation periods. After contact with pesticides, tubes were placed at $16^{\circ} \mathrm{C}$ in an oven for 4 hours in the dark. Hemocyte activities were measured by flow cytometry. The experiment was repeated three times with 50 oysters for each experiment. Concentration 1000X was also tested (data not shown).

\subsubsection{Test of metaldehyde alone}


Assays were performed in order to test metaldehyde effects at high concentrations: $100 \mathrm{mg} / \mathrm{L}$ and $1000 \mathrm{mg}$ / L with an incubation period of 4 hours and hemocytes were collected at the same time. Hemocytes were collected from oysters belonging to Family $n^{\circ} 29$, and different hemocyte parameters were measured by flow cytometry: cell size and complexity (data not shown), hemocyte mortality, presence of non-specific esterases, intracytoplasmic calcium (data not shown), presence and activities of lysosomes (data not shown) and phagocytic activity (data not shown). Safety data sheet Sigma-Aldrich reports EC50 test on 1 Daphnia specie allowing to define a value at $90 \mathrm{mg} / \mathrm{L}$ for Daphnia magna after a $48 \mathrm{~h}$ exposure. The experiment was repeated twice with 50 oysters for each experiment. A control with a salinity of $6.5 \%$ was added to check the validity of the protocols. Haemolymphs containing hemocytes were resuspended in a haemolymphe-distilled water mixture (haemolymphe / distilled water: $1 \mathrm{vol} / 4 \mathrm{vol}$ ) in order to obtain a salinity at $6.5 \%$.

\subsection{Statistical analysis}

Results were expressed as percentage of positive cells. Statistical analysis was performed using the Wilcoxon - Mann Whitney test by statistical software R, to compare two groups. The Kruskal-Wallis test was used to compare more than two groups. The null hypothesis (H0) corresponding to the distribution of the quantitative variable is the same in the groups. Significance was set at $\mathrm{p} \leq 0.05\left({ }^{*}\right)$ and at $\mathrm{p} \leq 0.01\left({ }^{* * *}\right)$.

\section{Results}

3.1. Test of different times of incubation of the pesticide mixture

Regardless of sample collection time, incubation of the hemocytes with the pesticide mixture did not have any significant effect on the tested parameters (Figs. 1 and 2). However, differences 
related to collection time were observed, as hemocyte mortality after a $21 \mathrm{~h}$ incubation period was 3 times higher than after a $2 \mathrm{~h}$ or a $4 \mathrm{~h}$ incubation period (Figs. 1a, $1 \mathrm{~b}$ and $1 \mathrm{c})$. Cell mortality at 21h (Figs. 1a and 1c) was high (around 45\%) in controls avoiding measurement of hemocyte activities. It was therefore decided to select a single sampling time for the following experiments using a range of concentrations (1X, 5X,10X and 100X) (Table 1). No significant effect was observed between the different conditions for intracytoplasmic calcium (Fig. 2a), presence and activities of lysosomes (Fig. 2c) and phagocytic activity (Fig. 2e). Only one difference is observed for phagocytosis between $2 \mathrm{~h}$ and $4 \mathrm{~h}$ (Fig. 2e). These two times are fairly close and with almost no difference, it was decided to keep only the $4 \mathrm{~h}$ time for the next experiments. Family $\mathrm{n}^{\circ}$ 32 was also tested (data not shown) and results were similar to those obtained for Family n ${ }^{\circ} 11$.

\subsection{Test of various concentrations of pesticides}

No significant effect was reported on any of the hemocyte activities tested, regardless of pesticide concentration (1X to 100X) (Table 1) as a mixture, between control hemoctyes and pesticide treated ones (Fig. 3). Hemocyte mortality was less than $8 \%$ for control hemoctyes and pesticide treated ones (Fig. 3a). Concentration 1000X was also tested (data not shown) and results were similar to those obtained for other concentrations.

\subsection{Test of metaldehyde alone}

Neither of the tested metaldehyde concentrations had a significant effect on oyster hemocytes (Family $\mathrm{n}^{\circ}$ 29) (Figs. 4a and 5a). Results were similar to those obtained with the pesticide mixture (no effect) and validated thanks to the controls included in each experiment. Oyster hemocytes were incubated at a $6.5 \%$ salinity. Low salinity allowed to observe significant effects on hemocyte parameters including cell mortality (Figs. 4 and 5). Hemocyte mortality was 6 times 
higher at 6.5\% salinity compared to other conditions and control (Figs. 4a and 4b). This significant increase $(\mathrm{p}<0.01)$ of cell mortality was also related to changes in terms of nonspecific esterase activities (Figs. 5a, 5b and 5c), with a significant increase of the cell population (pop 1) showing no or low fluorescence (dead cells) (Fig. 5). A significant reduction $(\mathrm{p}<0.01)$ from the 2 other cell populations (alive cells) (Fig. 5) was also observed. 


\section{Discussion}

In the present work, it was decided to study the putative effects of pesticides using a mixture of 14 different molecules in order to better represent aquatic environments where a variety of substances may be simultaneously present (Gagnaire et al., 2006a; Renault, 2011) including herbicides and their metabolites (Lanyi \& Dinya, 2003; Sorensen et al., 2003; Vargha et al., 2005). In contrast metaldehyde was tested individually, as this molluscicide substance known to be toxic for snails (Dai et al., 2011) has the potential to display high toxicity for oysters.

In this work using 3 bi-parental families, Pacific oyster (Crassostrea gigas) hemocyte mortality and cell activities were not affected by pesticides in short-term in vitro assays. However, a low salinity (6.5\% versus $25 \%$ o to $35 \%$ o salinity in the field) had a measurable effect on heamocytes which confirmed the validity of the protocols used in the present study. These observations are consistent with results from the literature, showing an effect of a pesticide mixture on phagocytosis only at high concentrations, higher than those tested in the present study (Gagnaire et al.,2006a). Another study showed that only extreme temperature and salinity conditions had an impact on Pacific oyster hemoctyes maintained in vitro (Gagnaire et al., 2006b).

The lack of noticeable effects of the pesticide mixture on oysters hemocytes could be partially explained by antagonistic effects between some of the substances, similar to those reported for diuron and its metabolites (Knauert et al., 2008; Pesce et al., 2010; Neuwoehner et al., 2010). It could also be related to the parameters selected to assess hemocyte activities: cell mortality, nonspecific esterase activities, lysosome detection, intra-cytoplasmic calcium and phagocytic activity. However, previous studies showed modulation of these parameters including phagocytosis. In the eastern osyter, $C$. virginica, reduced phagocytosis activity was observed after exposure to triforine (Alvarez and Friedl, 1992) and to the insecticide Chlordan at $250 \mu \mathrm{M}$ in vitro (Larson et al., 1989) which is higher than the concentrations used in the present study. 
Moreover, Canty et al. (2007) reported a decrease in phagocytic index in the blue mussel, Mytilus edulis, after a short exposure to 0.1 mg. $\mathrm{L}^{-1}$ azamethiphos suggesting that azamethiphos can modulate hemocyte functions in mussels at environmentally relevant concentrations. On the contrary, Gagnaire et al. (2003) reported no effect on cell viability, cell cycle and cellular activities except for peroxidase activity in Pacific cupped oyster hemocytes exposed to atrazine in vitro. On the contrary, effects have been reported in in vivo conditions on these parameters (Gagnaire et al., 2007).

Monitoring of hemocyte parameters may be compromised by high inter-individual variability (Ordás et al., 2000; Ford \& Paillard, 2007). In order to address this issue and minimize effects related to the genetic diversity, animals belonging to 3 hatchery-reared bi-parental families rather than oysters collected from the field were used as biological material.

The short exposure times that were used in the present experiments could partially account for the observed results. However, aquatic organisms have displayed susceptibility to short-term exposure to herbicides under laboratory controlled conditions (Bretaud et al., 2000; Saglio et al., 2002; Gagnaire et al., 2006a and b). Moreover, in the natural aquatic environment, peak concentrations are often found for short periods of time (Munaron, 2006; Hyne et al., 2008). Although pesticides may demonstrated some effects on hemocytes after long exposure in in vivo experiments (Patetsini et al., 2013), testing of long exposure period is difficult in in vitro assays as hemocytes do not survive for long time outside of oysters.

Although levels of pesticides measured in superficial waters generally range below lethal concentrations for aquatic species, several studies concerning the effects of pesticides in bivalves have been carried out using high pollutant concentrations. In the present study, pesticides were tested at environmentally relevant concentrations in order to document putative sub-lethal adverse effects. The lack of impact of pesticide exposure on hemocytes could be attributed to the 
low concentrations of pesticicides that were used. However, this hypothesis appeared as not relevant as no effect was also observed on the assessed parameters when higher concentrations were tested.

Short-term exposure of hemocytes to different concentrations of pesticides had no significant effect on the assessed parametres, suggesting, that these cells have some level of resistance towards pesticides in vitro, under the tested conditions. This hypothesis is supported by data from the full genome sequencing of the Pacific oyster, which reveals the existence of stress adaptation in particular through the transcription of a large set of genes as a response to stressful environmental conditions (Zhang et al., 2012). As an example, 88 genes encoding heat shock proteins 70 (HSP70), which have crucial roles in protecting cells against heat and other stresses, were identified in the Pacific oyster genome, compared with $\sim 17$ in humans and 39 in sea urchins. Moreover, genomic and transcriptomic analyses of different biological processes such as apoptosis highlight the sophisticated genomic adaptations of this bivalve species to sessile life in a highly stressful environment (Zhang et al., 2012).

As a conclusion, it appears useful to carry out in vivo experiments to study the effects of shortterm exposure to pesticide mixtures and to define models of immune-modulation. Such models could improve our understanding of the complex interactions between Pacific oysters, pathogens and the environment including pesticides. Although a relationship between pollution and an increased susceptibility towards infectious diseases has been established in vertebrates (Fournier et al., 1988; Van Levoren et al., 2000; Jepson et al., 2005; Kim et al., 2008), few studies have been devoted to invertebrates (Galloway \& Depledge, 2001). Few studies have attempt to link contaminants and susceptibility to pathogens in marine molluscs (Anguiano et al., 2007; Gagnaire et al., 2007; Collin et al., 2010; Greco et al., 2011). Pacific cupped oysters, Crassostrea gigas, have been previously used as a model to evaluate the impact of a mixuture of pesticides on 
certain immune-related parameters and to demonstrate the relationship between bacterial infection, the presence of pollutants and the host's defense capacity (Gagnaire et al., 2007). This type of approach appears suitable to further understand the massive mortality outbreaks of Pacific oyster spat that have been reported in France since 2008 (Segarra et al., 2010; EFSA 2010).

\section{Acknowledgments}

This work was partially funded through the EU project BIVALIFE (26 61 57) and the Poitou Charentes Region. Thank you to Valerie Barbosa-Solomieu for English editing. 


\section{References}

Alvarez MR, Friedl FE. Effects of a fungicide on in vitro hemocyte viability, phagocytosis and attachment in the American oyster, Crassostrea virginica. Aquaculture 1992;107:135-40.

Anguiano G, Llera-Herrera R, Rojas E, Vazquez-Boucard C. Subchronic organismal toxicity, cytotoxicity, genotoxicity, and feeding response of Pacific oyster (Crassostrea gigas) to lindane (gamma-HCH) exposure under experimental conditions. Environ. Toxicol. Chem. 2007;26:2192-7.

Aton E, Renault T, Gagnaire B, Thomas-Guyon H, Cognard C, Imbert N. A flow cytometric approach to study intracellular-free $\mathrm{Ca} 2+$ in Crassostrea gigas haemocytes. Fish Shellfish Immunol. 2006;20:493-502.

Baier-Anderson C, Anderson RS. The effects of chlorothalonil on oyster hemocyte activation: phagocytosis, reduced pyridine nucleotides, and reactive oxygen species production. Environ. Res. 2000;83:72-8.

Banerjee BD, Koner BC, Ray A. Immunotoxicity of pesticides: perspectives and trends. Indian J. Exp. Biol. 1996;34:723-33.

Banerjee BD, Seth V, Ahmed RS. Pesticide-induced oxidative stress: perspectives and trends. Rev Environ Health 2001;16:1-40.

Bretaud S, Toutant JP, Saglio P. Effects of carbofuran, diuron, and nicosulfuron on acetylcholinesterase activity in goldfish (Carassius auratus). Ecotoxicol. Environ. Saf. 2000;47:117-24.

Cajaraville MP, Olabarrieta I, Marigomez I. In vitro activities in mussel hemocytes as biomarkers of environmental quality: a case study in the Abra Estuary (Biscay Bay). Ecotoxicol. Environ. Saf. 1996;35:253-60.

Canty MN, Hagger JA, Moore RTB, Cooper L, Galloway TS. Sublethal impact of short term exposure to the organophosphate pesticide azamethiphos in the marine mollusc Mytilus edulis. Mar. Pollut. Bull. 2007;54:396-402.

Cheng T.C. Bivalves. N.A. Ratcliffe, A.F. Rowley (Eds.), Invertebrate Blood Cells, Academic Press, London. 1981; pp. 233-299.

Coles JA, Pipe RK. Phenoloxidase activity in the haemolymph and haemocytes of the marine mussel Mytilus edulis. Fish \& Shellfish Immunology 1994;4:337-52.

Collin H, Meistertzheim A-L, David E, Moraga D, Boutet I. Response of the Pacific oyster Crassostrea gigas, Thunberg 1793, to pesticide exposure under experimental conditions. J. Exp. Biol. 2010;213:4010-7.

Dai L, Wang W, Dong X, Hu R, Nan X. Molluscicidal activity of cardiac glycosides from Nerium indicum against Pomacea canaliculata and its implications for the mechanisms of toxicity. Environ. Toxicol. Pharmacol. 2011;32:226-32.

EFSA (European Food Safety Authority), 2010. Scientific Opinion on the increased mortality events in Pacific oysters, Crassostrea gigas. EFSA Journal 2010;8(11):1894.

Feng SY. Cellular defense mechanisms of oysters and mussels. Am Fish Soc Spec Publ. 1988;18:153-168.

Ford SE, Paillard C. Repeated sampling of individual bivalve mollusks I: intraindividual variability and consequences for haemolymph constituents of the Manila clam, Ruditapes philippinarum. Fish Shellfish Immunol. 2007;23:280-91.

Fournier M, Chevalier G, Nadeau D, Trottier B, Krzystyniak K. Virus-pesticide interactions with murine cellular immunity after sublethal exposure to dieldrin and aminocarb. J Toxicol Environ Health 1988;25:103-18. 
Fournier Michel, Cyr D, Blakley B, Boermans H, Brousseau P. Phagocytosis as a Biomarker of Immunotoxicity in Wildlife Species Exposed to Environmental Xenobiotics. Amer. Zool. 2000;40:412-20.

Gagnaire B, Renault T, Bouilly K, Lapegue S, Thomas-Guyon H. Study of atrazine effects on Pacific oyster, Crassostrea gigas, haemocytes. Curr. Pharm. Des. 2003;9:193-9.

Gagnaire B, Thomas-Guyon H, Burgeot T, Renault T. Pollutant effects on Pacific oyster, Crassostrea gigas (Thunberg), hemocytes: screening of 23 molecules using flow cytometry. Cell Biol. Toxicol. 2006a;22:1-14.

Gagnaire Beatrice, Frouin H, Moreau K, Thomas-Guyon Helene, Renault Tristan. Effects of temperature and salinity on haemocyte activities of the Pacific oyster, Crassostrea gigas (Thunberg). Fish Shellfish Immunol. 2006b;20:536-47.

Gagnaire Beatrice, Gay M, Huvet A, Daniel J-Y, Saulnier D, Renault Tristan. Combination of a pesticide exposure and a bacterial challenge: In vivo effects on immune response of Pacific oyster, Crassostrea gigas (Thunberg). Aquatic Toxicology 2007;84:92-102.

Galloway TS, Depledge MH. Immunotoxicity in invertebrates: measurement and ecotoxicological relevance. Ecotoxicology 2001;10:5-23.

Galloway T, Handy R. Immunotoxicity of organophosphorous pesticides. Ecotoxicology 2003;12:345-63.

Greco L, Pellerin J, Capri E, Garnerot F, Louis S, Fournier M, Sacchi A, Fusi M, Lapointe D, Couture P. Physiological effects of temperature and a herbicide mixture on the soft-shell clam Mya arenaria (Mollusca, Bivalvia). Environ. Toxicol. Chem. 2011;30:132-41.

Hyne RV, Aistrope M. Calibration and field application of a solvent-based cellulose membrane passive sampling device for the monitoring of polar herbicides. Chemosphere 2008;71:61120.

Jepson PD, Bennett PM, Deaville R, Allchin CR, Baker JR, Law RJ. Relationships between polychlorinated biphenyls and health status in harbor porpoises (Phocoena phocoena) stranded in the United Kingdom. Environ. Toxicol. Chem. 2005;24:238-48.

Kim Y, Powell EN, Wade TL, Presley BJ. Relationship of parasites and pathologies to contaminant body burden in sentinel bivalves: NOAA Status and Trends "Mussel Watch" Program. Mar. Environ. Res. 2008;65:101-27.

Knauert S, Escher B, Singer H, Hollender J, Knauer K. Mixture toxicity of three photosystem II inhibitors (atrazine, isoproturon, and diuron) toward photosynthesis of freshwater phytoplankton studied in outdoor mesocosms. Environ. Sci. Technol. 2008;42:6424-30.

Kouassi, Edouard, Ayotte, Pierre, Roy, Raynald, Fournier, Michel, Revillard, Jean-Pierre. BISE | Effets des contaminants de l'environnement sur le système immunitaire. 2001. Available at: http://www.inspq.qc.ca/bise/post/2001/04/20/Effets-des-contaminants-dele28099environnement-sur-le-systeme-immunitaire.aspx\#.

Lanyi K., Dinya Z. Photodegradation study of some triazine-type herbicides. Microchemical Journal 2003;75:1-13.

Larson KG, Roberson BS, Hetrick FM. Effect of environmental pollutants on the chemiluminescence of hemocytes from the American oyster Crassostrea virginica. Diseases of aquatic organisms 1989;6:131-6.

Luna-Acosta A, Kanan R, Le Floch S, Huet V, Pineau P, Bustamante P, Thomas-Guyon H. Enhanced immunological and detoxification responses in Pacific oysters, Crassostrea gigas, exposed to chemically dispersed oil. Water Res. 2011;45:4103-18.

Masuda M, Satsuma K, Sato K. An environmental fate study of methoxychlor using watersediment model system. Biosci. Biotechnol. Biochem. 2012;76:73-7. 
Menin A, Ballarin L, Bragadin M, Cima F. Immunotoxicity in ascidians: antifouling compounds alternative to organotins - II. The case of Diuron and TCMS pyridine. J Environ Sci Health B 2008;43:644-54.

Munaron D, Dubernet JF, Delmas F, Stanisière JY, Scribe P. Assessment of the quantities of herbicides and nutrients brought down by the river Charente to the coast and modelling of the dispersion of atrazine in the Marennes-Oléron bay 2006. http://cemadoc.irstea.fr/cemoa/PUB00022983.

Neuwoehner J, Zilberman T, Fenner K, Escher BI. QSAR-analysis and mixture toxicity as diagnostic tools: Influence of degradation on the toxicity and mode of action of diuron in algae and daphnids. Aquat. Toxicol. 2010;97:58-67.

Patetsini E, Dimitriadis VK, Kaloyianni M. Biomarkers in marine mussels, Mytilus galloprovincialis, exposed to environmentally relevant levels of the pesticides, chlorpyrifos and penoxsulam. Aquatic Toxicology 2013;126:338-45.

Pesce S, Lissalde S, Lavieille D, Margoum C, Mazzella N, Roubeix V, Montuelle B. Evaluation of single and joint toxic effects of diuron and its main metabolites on natural phototrophic biofilms using a pollution-induced community tolerance (PICT) approach. Aquat. Toxicol. 2010;99:492-9.

Ordás MC, Ordás A, Beloso C, Figueras A. Immune parameters in carpet shell clams naturally infected with Perkinsus atlanticus. Fish Shellfish Immunol. 2000;10:597-609.

Renault T. Effects of Pesticides on Marine Bivalves: What Do We Know and What Do We Need to Know? In: Stoytcheva M, editor. Pesticides in the Modern World - Risks and Benefits. InTech; October 3, 2011.

Ross MW. Managing HIV. Part 3: Mechanisms of disease. 3.8 How psychosocial aspects of HIV infection can affect health. Med. J. Aust. 1996;164:235-7.

Saglio P, Bretaud S, Rivot E, Olsén KH. Chemobehavioral Changes Induced by Short-Term Exposures to Prochloraz, Nicosulfuron, and Carbofuran in Goldfish. Arch Environ Contam Toxicol 2003;45:515-24.

Savage C, Thrush SF, Lohrer AM, Hewitt JE. Ecosystem services transcend boundaries: estuaries provide resource subsidies and influence functional diversity in coastal benthic communities. PLoS ONE 2012;7:e42708.

Segarra A, Pépin JF, Arzul I, Morga B, Faury N, Renault T. Detection and description of a particular Ostreid herpesvirus 1 genotype associated with massive mortality outbreaks of Pacific oysters, Crassostrea gigas, in France in 2008. Virus Res. 2010;153:92-9.

Sørensen SR, Bending GD, Jacobsen CS, Walker A, Aamand J. Microbial degradation of isoproturon and related phenylurea herbicides in and below agricultural fields. FEMS Microbiol. Ecol. 2003;45:1-11.

Tanguy A, Boutet I, Laroche J, Moraga D. Molecular identification and expression study of differentially regulated genes in the Pacific oyster Crassostrea gigas in response to pesticide exposure. FEBS J. 2005;272:390-403.

Van Loveren H, Ross PS, Osterhaus AD, Vos JG. Contaminant-induced immunosuppression and mass mortalities among harbor seals. Toxicol. Lett. 2000;112-113:319-24.

Vargha M, Takáts Z, Márialigeti K. Degradation of atrazine in a laboratory scale model system with Danube river sediment. Water Res. 2005;39:1560-8.

Vial T, Nicolas B, Descotes J. Clinical immunotoxicity of pesticides. J Toxicol Environ Health 1996;48:215-29.

Zhang G, Fang X, Guo X, Li L, Luo R, Xu F, et al. The oyster genome reveals stress adaptation and complexity of shell formation. Nature 2012;490:49-54. 


\section{Figure legends}

Figure 1. Hemocyte activities after exposure to the pesticides mixture at $1 \mathrm{X}$ concentration for Family $n^{\circ} 11$ (a) Hemocyte mortality percentage after $2 \mathrm{~h}, 4 \mathrm{~h}$ and $21 \mathrm{~h}$ exposure periods to pesticides. (b) Flow cytometry cytogram demonstrating cells mortality percentage after a 4h exposure period. (c) Flow cytometry cytogram demonstrating cells mortality percentage after a $21 \mathrm{~h}$ exposure period

Figure 2. Hemocyte activities tested after exposure to the pesticides mixture at $1 \mathrm{X}$ concentration for Family $\mathrm{n}^{\circ} 11$. (a) Percentage of intracytoplasmic calcium positive cells after $2 \mathrm{~h}$ and 4h exposure. (b) Flow cytometry cytogram of cells stained with Fluo-4 AM after a 4h incubation period. Horizontal-axis: intensity of fluorescence; Vertical-axis: number of cells; (pop 1) population considerated as negative cells; (pop 2) population of moderately stained cells; (pop 3) population of strongly stained cells. (c) Percentage of lysosomes positive cells after $2 \mathrm{~h}$ and $4 \mathrm{~h}$ exposure periods. (d) Flow cytometry cytogram of cells stained with Lysotracker Green DND-26 after a 4h incubation period. Horizontal-axis: intensity of fluorescence; Vertical-axis: number of cells; (pop 1) population considerated as negative cells; (pop 2) population of moderately stained cells; (pop 3) population of strongly stained cells. (e) Percentage of positive cells for phagocytic activity after $2 \mathrm{~h}$ and 4h exposure periods

Figure 3. Hemocyte activities after exposure to the pesticide mixture at $1 \mathrm{X}$ concentration for Family $\mathrm{n}^{\circ}$ 29. (a) Hemocyte mortality percentage after a $4 \mathrm{~h}$ exposure period. (b) Percentage of intracytoplasmic calcium positive cells after a $4 \mathrm{~h}$ exposure period. (c) Percentage of lysosomes positive cells after a $4 \mathrm{~h}$ exposure period. (d) Percentage of phagocytic activity positive cells after a 4 h exposure period

Figure 4. Hemocyte activities after exposure to metaldehyde alone for Family $\mathrm{n}^{\circ}$ 29. (a) Hemocyte mortality percentage after a $4 \mathrm{~h}$ exposure period at $100 \mathrm{mg} / \mathrm{L}$ and $1 \mathrm{~g} / \mathrm{L}$, and after exposure to a 6.5\% salinity. (b) Flow cytometry cytogram demonstrating cells mortality percentages after a $4 \mathrm{~h}$ exposure period to a salinity at $6.5 \%$

Figure 5. Hemocyte activities after exposure to metaldehyde alone for Family $\mathrm{n}^{\circ}$ 29. (a) Percentage of non-specific esterase positive cells after a $4 \mathrm{~h}$ exposure period at $100 \mathrm{mg} / \mathrm{L}$ and $1 \mathrm{~g} / \mathrm{L}$, and after exposure at 6.5\% salinity. (b) Flow cytometry cytogram of cells stained with FDA at $100 \mathrm{mg} / \mathrm{L}$ of metaldehyde (4h condition). Horizontal-axis: intensity of fluorescence for non-specific esterase activities; Vertical-axis: number of cells; (pop 1) population considerated as negative cells; (pop 2) population of moderately stained cells; (pop 3) population of strongly stained cells. (c) Flow cytometry cytogram of cells stained with FDA after exposure to at $6.5 \%$ salinity (4h condition). Horizontal-axis: intensity of fluorescence for non-specific esterase activities; Vertical-axis: number of cells: (pop 1) population considerated as negative cells; (pop 2) population of moderately stained cells; (pop 3) population of strongly stained cells 
Table 1. Final concentrations of the pesticide mixture in presence of hemocytes and the solvents used 


\section{Table 1}

\begin{tabular}{cccccc}
\hline Pesticides (solvent) & Groupe & $\begin{array}{c}\text { Concentration } \\
\boldsymbol{\mu g} / \mathbf{L}(\mathbf{1} \mathbf{x})^{*}\end{array}$ & $\begin{array}{c}\text { Concentration } \\
\boldsymbol{\mu g} / \mathbf{L}(\mathbf{1 0 x})\end{array}$ & $\begin{array}{c}\text { Concentration } \\
\boldsymbol{\mu g} / \mathbf{L}(\mathbf{5 0 x})\end{array}$ & $\begin{array}{c}\text { Concentration } \\
\boldsymbol{\mu g} / \mathbf{L}(\mathbf{1 0 0 x})\end{array}$ \\
\hline Carbaryl (CH) & Insecticide & 0.05 & 0.5 & 2.5 & 5 \\
Fosetyl Al & Fongicide & 0.6 & 6 & 30 & 60 \\
Alachlor (MeOH) & Herbicide & 0.8 & 8 & 40 & 80 \\
Métolachlor (AN) & Herbicide & 1 & 10 & 50 & 100 \\
Glyphosate & Herbicide & 4 & 40 & 200 & 400 \\
Atrazine (MeTE) & Herbicide & 0.1 & 1 & 5 & 10 \\
Terbuthylazine & Herbicide & 0.6 & 6 & 30 & 60 \\
Diuron & Herbicide & 2 & 20 & 100 & 200 \\
AMPA & Herbicide & 2.5 & 25 & 125 & 250 \\
Bentazon & Herbicide & 0.5 & 5 & 25 & 50 \\
Tebuconazol & Fongicide & 3 & 30 & 150 & 300 \\
Imidacloprid (AN) & Insecticide & 0.1 & 1 & 5 & 10 \\
Mancozeb & Fongicide & 0.1 & 1 & 5 & 10 \\
Metaldehyde & Molluscicide & 0.1 & 1 & 5 & 10 \\
\hline
\end{tabular}

Solvents: $\mathrm{CH}$. cyclohexane; $\mathrm{MeOH}$. methanol; AN. acetonitrile; MeTE. methyl terbutyl ether

* environmentaly relevant concentrations 


\section{Figure 1}

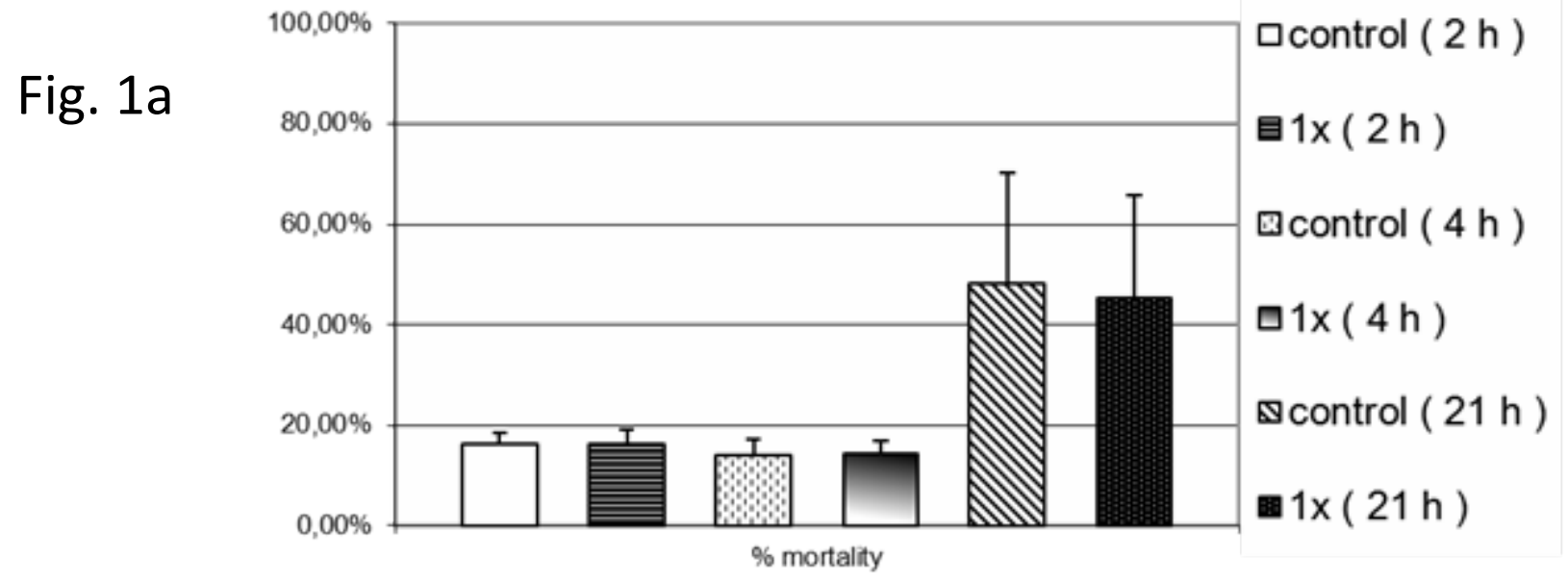

Fig. 1b

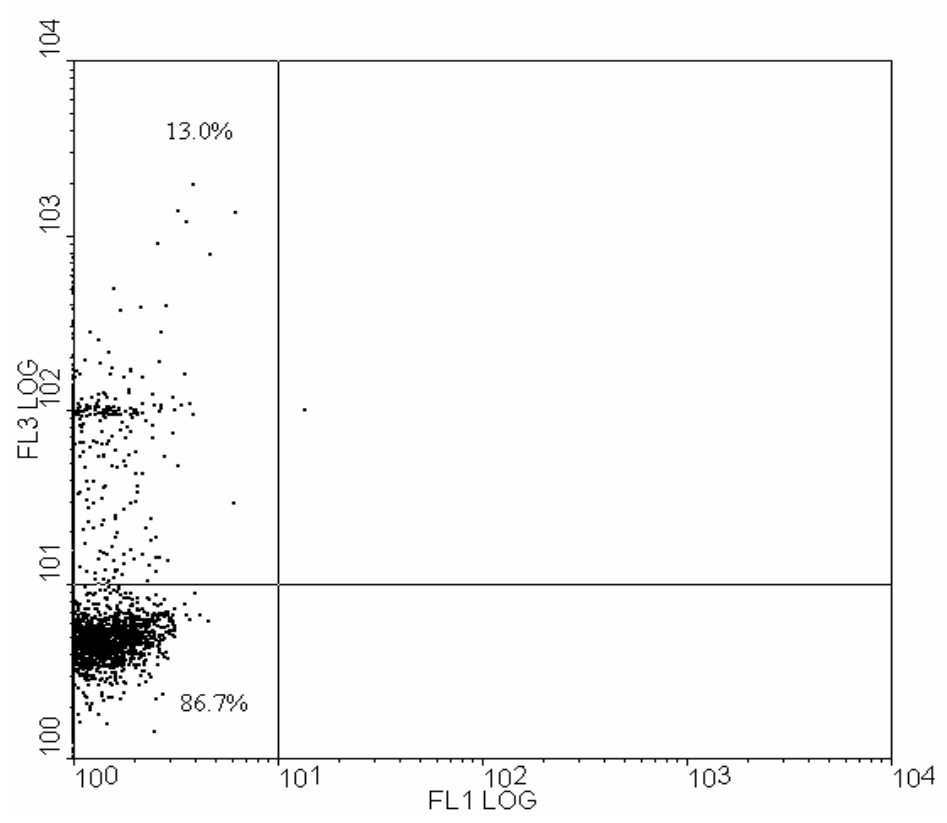

Fig. 1c

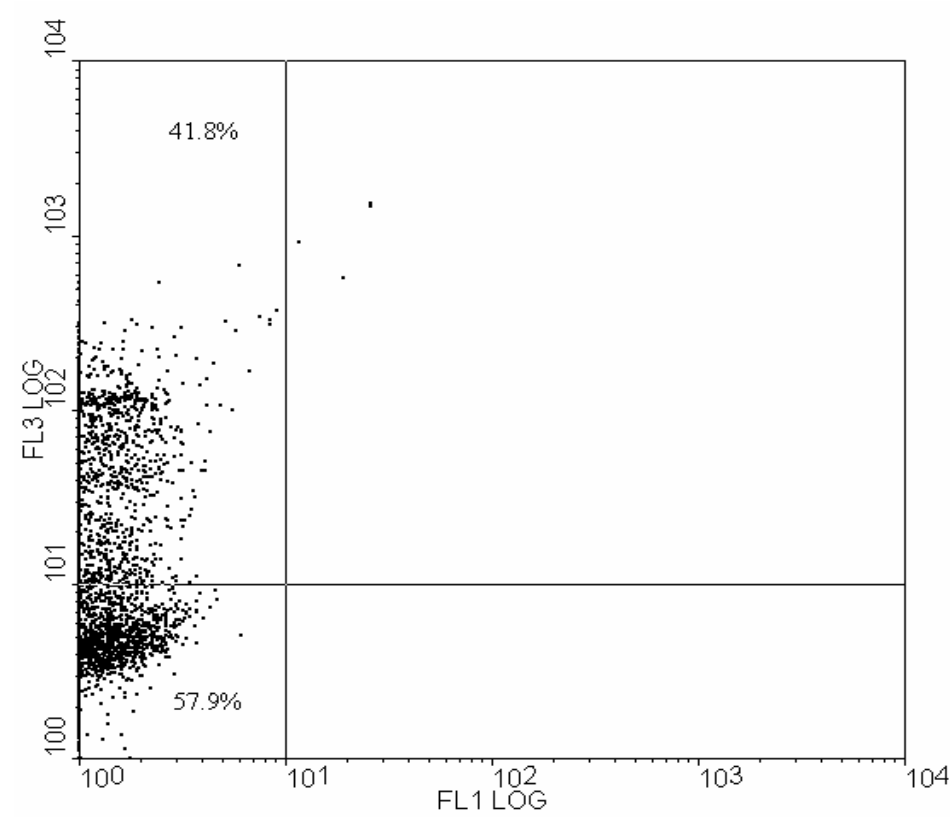


Figure 2

Fig. 2a

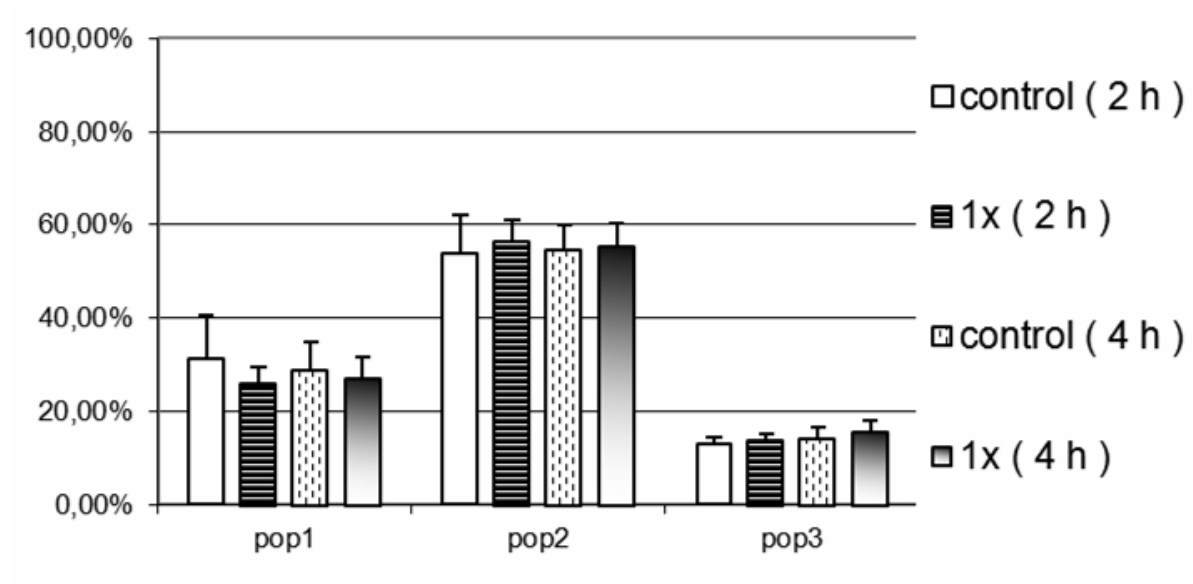

Fig. 2c
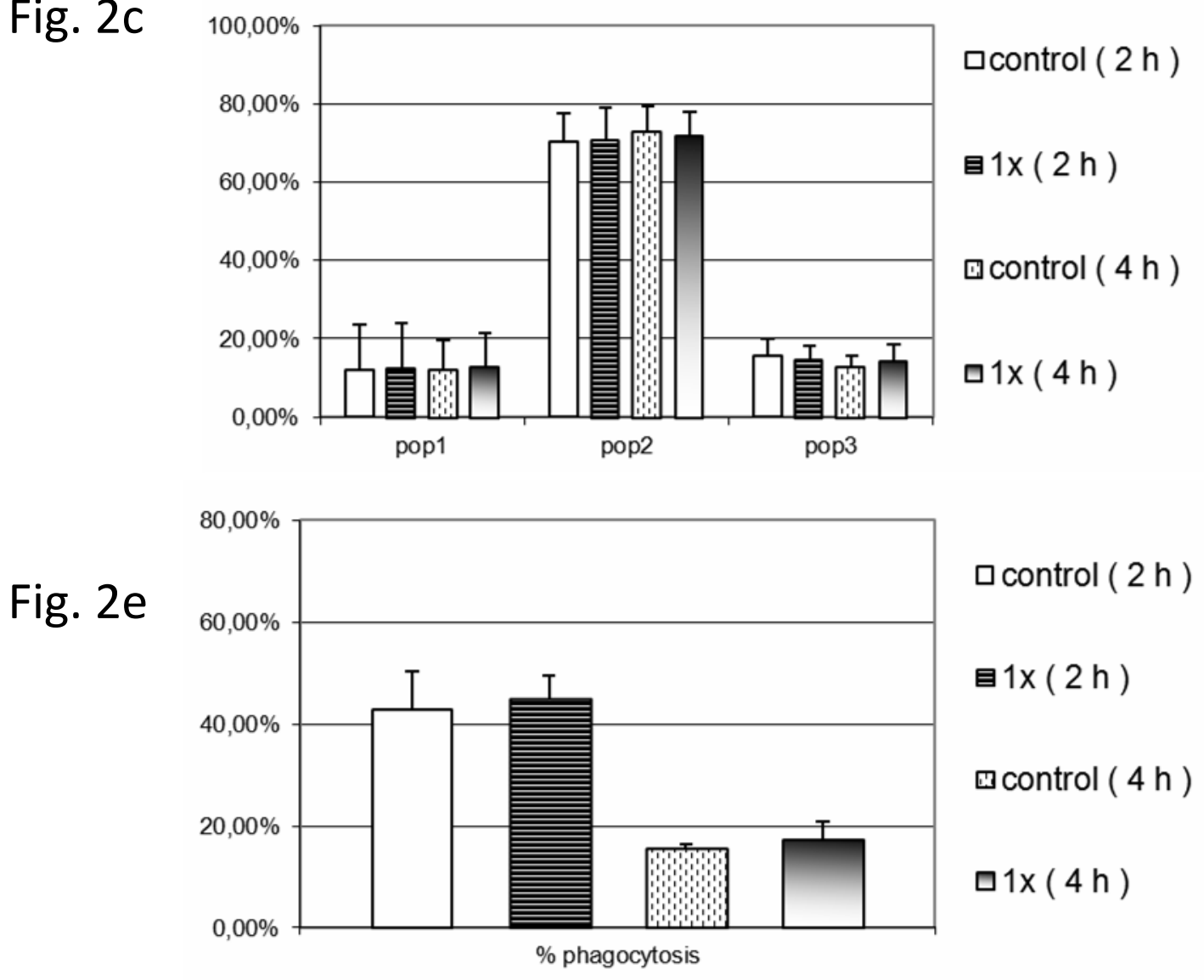

Fig. $2 b$

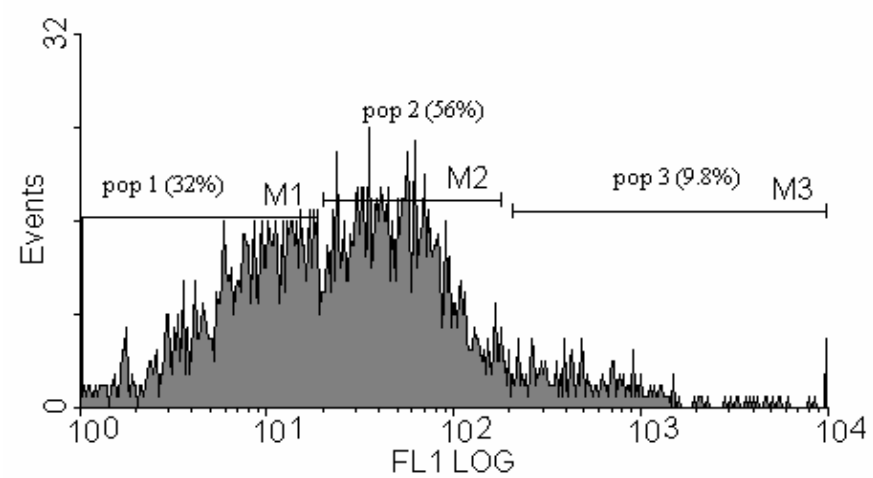

Fig. 2d

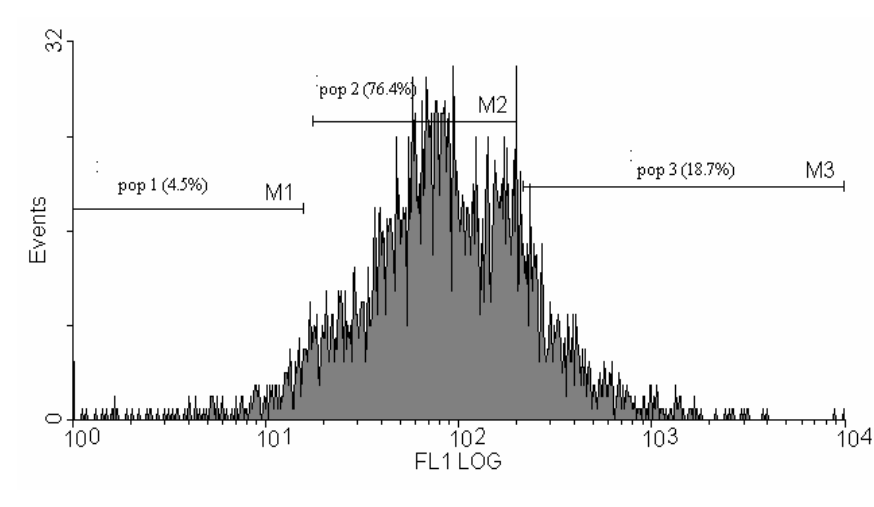




\section{Figure 3}

Fig. 3a

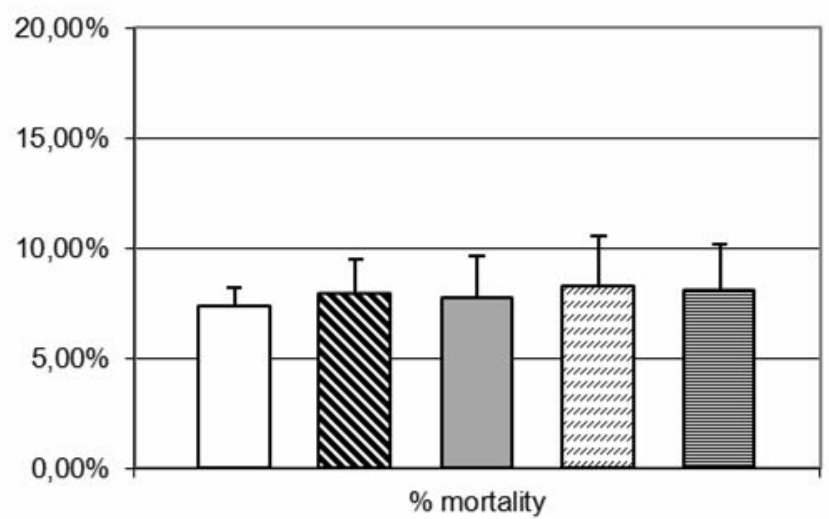

Fig. 3c

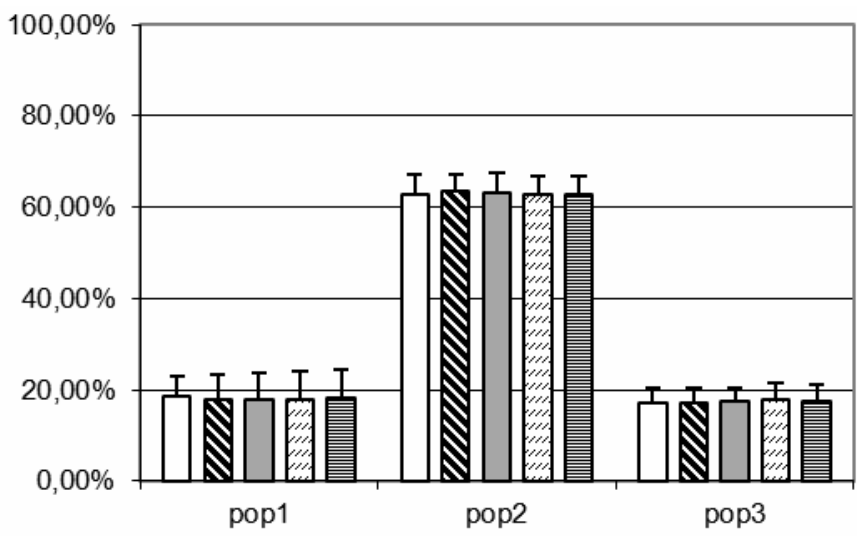

Fig. 3b
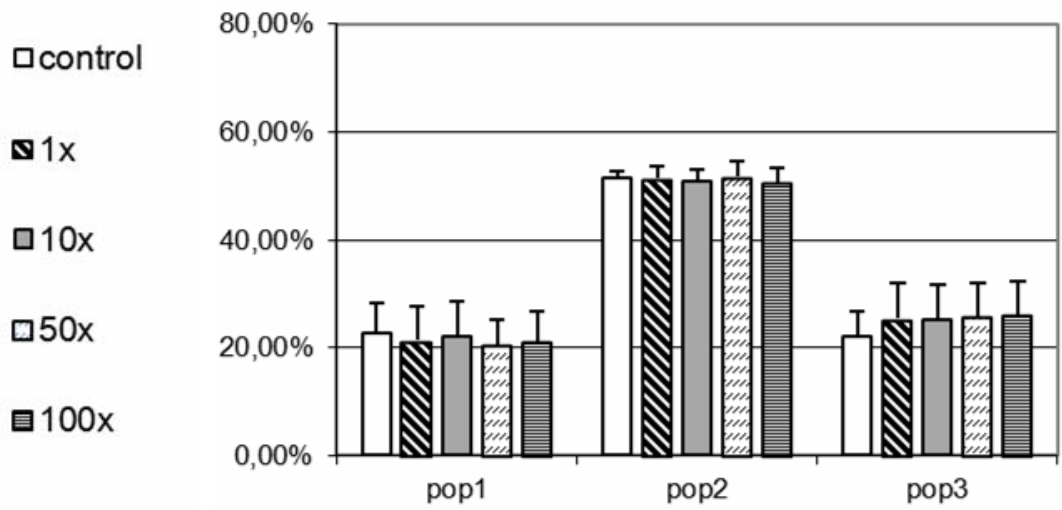

$\square$ control

ब $1 \mathrm{x}$

10x

$\square 50 x$

目 $100 x$

Fig. 3d

$\square$ control

$\mathbf{v} 1 \mathrm{x}$

ㅁ10x

๑50x

目 $100 x$

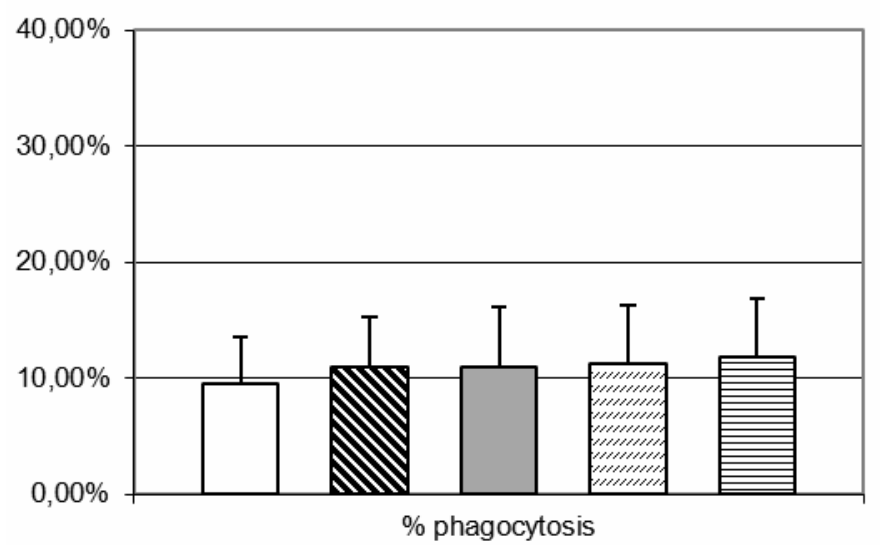

acontrol

$\mathbf{v} 1 \mathrm{x}$

10x

๑50x

目100x 


\section{Figure 4}

Fig. 4a

Fig. 4b

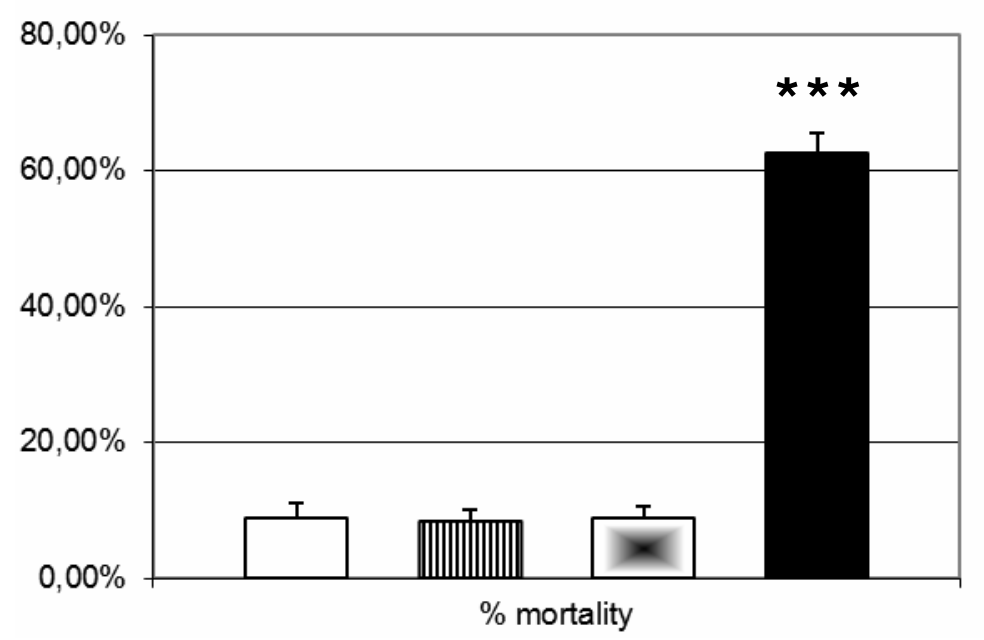

$\square$ control

m 100mg/L

$\square 1 \mathrm{~g} / \mathrm{L}$

- salinity 6,5

$\%$

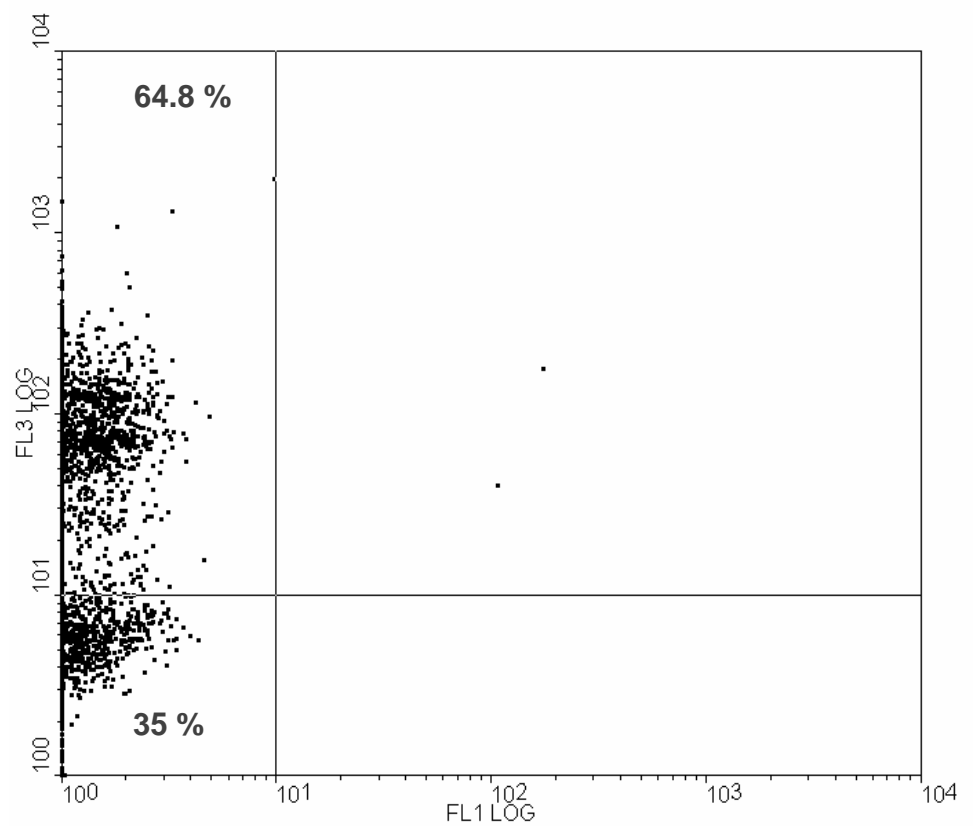


Figure 5

Fig. 5a

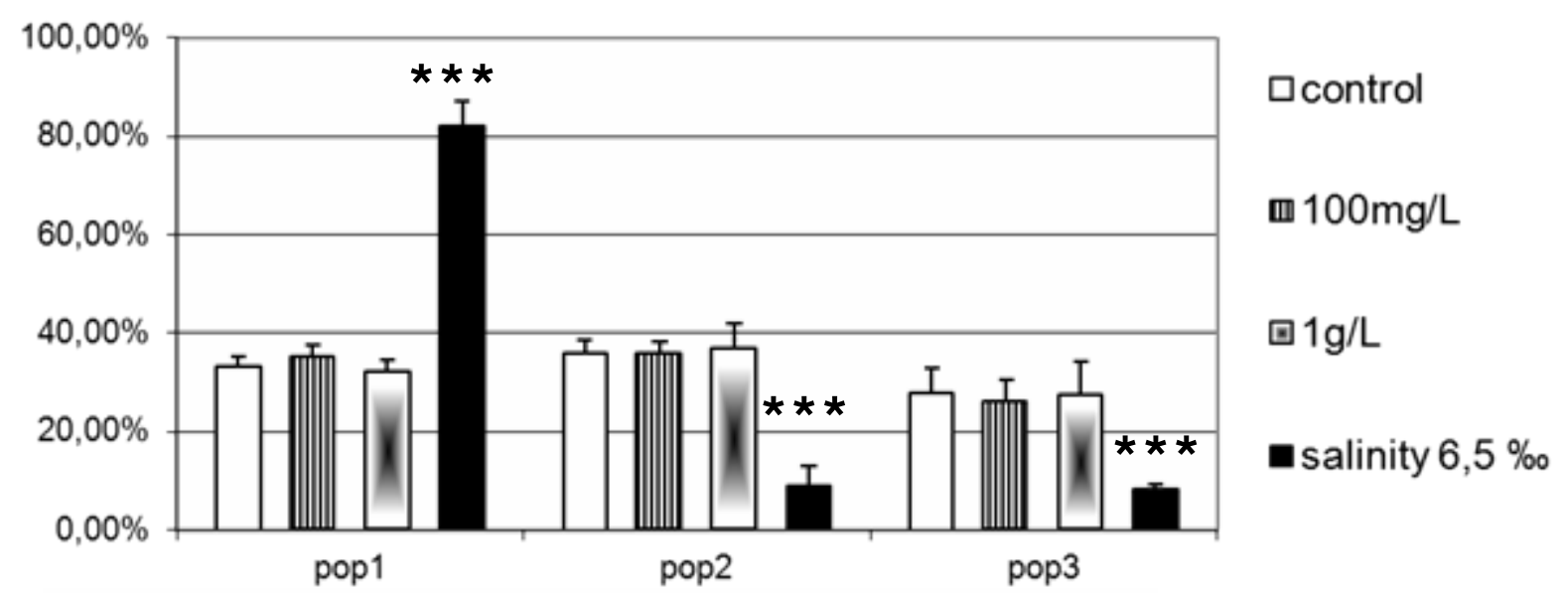

Fig. 5b

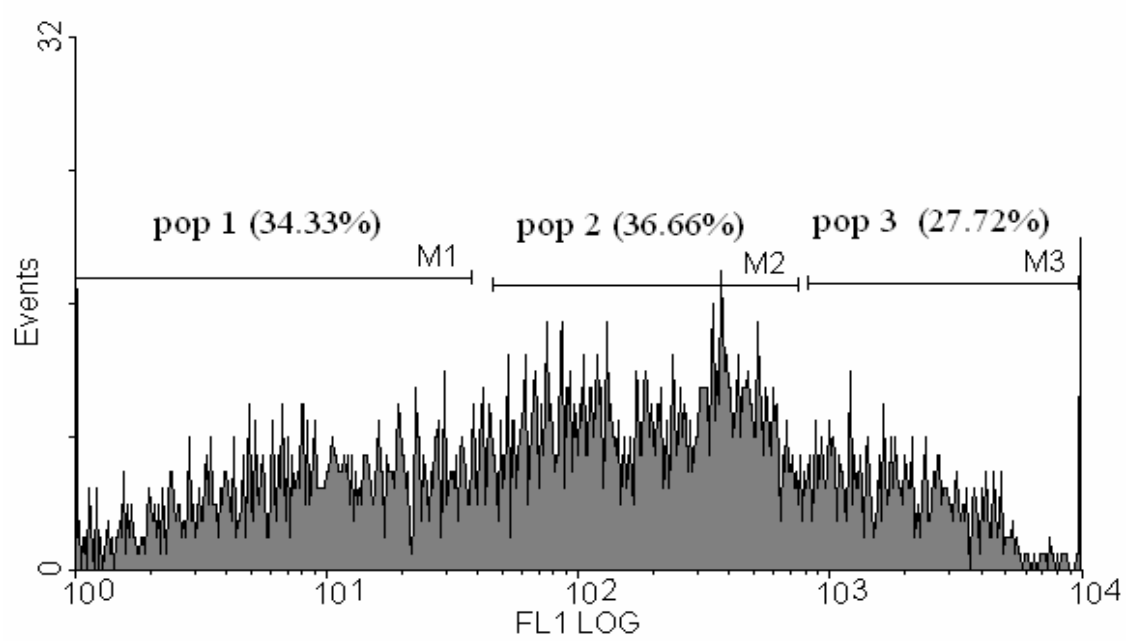

Fig. 5c

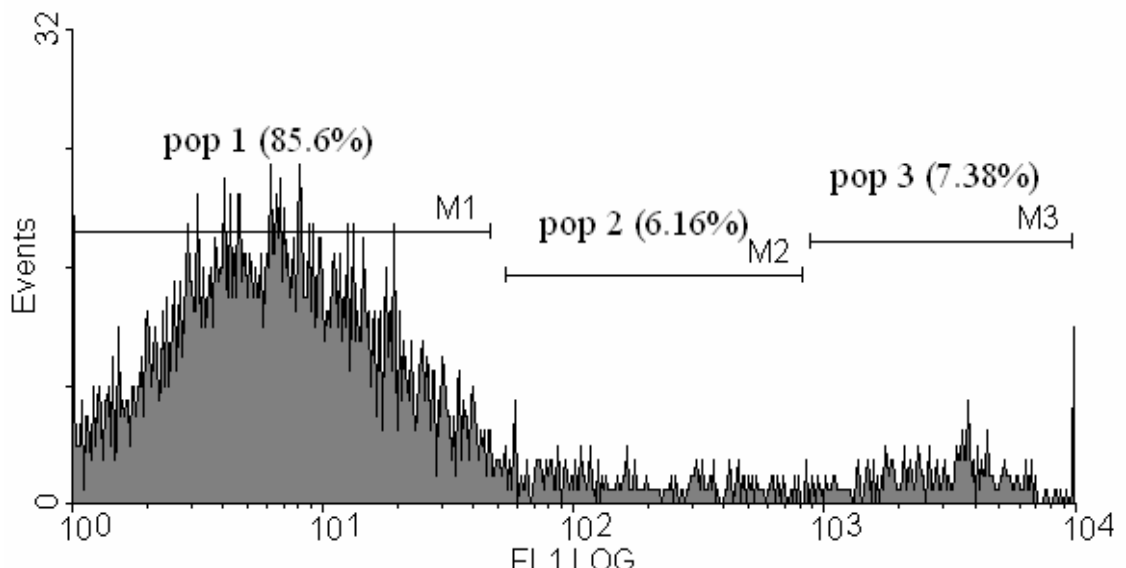

